\title{
OS PARADOXOS DO CONSUMO
}

\author{
Por Isleide A. Fontenelle \\ Professora da Escola de Administração de Empresas de São Paulo, Fundação Getulio Vargas \\ E-mail: isleide.fontenelle@fgv.br
}

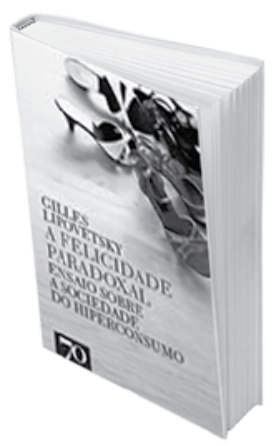

A FELICIDADE PARADOXAL: ENSAIO SOBRE A SOCIEDADE DE HIPERCONSUMO

De Gilles Lipovetsky

São Paulo: Companhia das Letras, 2007. 402 p.

Os textos do filósofo francês Gilles Lipovestky estão disponíveis aos leitores brasileiros há duas décadas. Desde o final dos anos 1980, com a publicação de seu excelente livro $O$ império do efêmero (Companhia das Letras, $2^{\mathrm{a}}$ edição, 1989) - um estudo da moda como fenômeno ocidental moderno -, o autor aborda fenômenos como a moda, o luxo, o lazer, a mídia, a publicidade, o consumo, que servem de fio condutor para a teorização sobre o individualismo, a alienação, a liberdade, a felicidade. Polêmico por propor uma leitura mais tolerante da cultura de consumo, defende que a lógica sedutora da mercadoria manipula, mas também pode ser um mecanismo de emancipação dos sujeitos. Já foi classificado por seus críticos como um autor pós-moderno por, de fato, ter tomado esse conceito como categoria explicativa para uma nova condição social e histórica das sociedades ocidentais. Entretanto, em seus últimos escritos, como em Os tempos hipermo- dernos (BARCAROLLA, 2004), assume que o pós-moderno foi um estágio passageiro da hipermodernização do mundo, ou seja, de uma intensificação de fenômenos que sempre caracterizaram a modernidade, tais como o individualismo.

Seu mais recente livro remete-nos aos paradoxos da felicidade. Contudo, o subtítulo revela mais claramente a essência do texto: uma reflexão sobre a constituição da sociedade de hiperconsumo; e sobre a possibilidade ou não de realização da promessa moderna de felicidade, caracterizada como ideal supremo de nossa época. Na aparência, essa sociedade não difere muito da sociedade de consumo da segunda metade do século XX, denominada pelo autor "civilização do desejo"; mas o olhar atento de Lipovetsky capta e discute os sinais, funcionamento e impacto de uma nova etapa.

Para caracterizar o atual estágio de consumo, Lipovetsky reconstitui a história das diferentes fases do capi- talismo de consumo. O primeiro ciclo, iniciado por volta dos anos 1880 , avança até a Segunda Guerra Mundial. Trata-se da constituição da produção e do consumo de massa, da invenção do marketing e da construção do consumidor moderno, surgindo o consumosedução e o consumo-distração, dos quais ainda somos herdeiros fiéis.

O segundo ciclo começa por volta de 1950 e se consolida ao longo das três primeiras décadas do pós-guerra. Chamado período áureo do capitalismo keynesiano, é considerado por Lipovetsky como o modelo mais puro da sociedade de consumo de massa. Nele, ocorrem a revolução comercial sem precedentes e o início das novas estratégias do marketing de segmentação de mercado, baseadas em fatores demográficos e socioculturais. Aqui, Lipovetsky demonstra a relação que pretende estabelecer entre felicidade e consumo, considerando que essa sociedade é guiada pela idéia de progresso como sinônimo de melhoria 
das condições de vida. Por sua vez, a felicidade liga-se a um cotidiano confortável, em função dos objetos de consumo. Para Lipovetsky, o esgotamento desse ciclo dá lugar a uma nova fase na história do consumo: a do hiperconsumo.

A sociedade do hiperconsumo caracteriza-se pela amplificação da mentalidade de consumo das etapas anteriores, chegando aos espaços até então considerados não mercantilizáveis - tais como a família, a escola, a ética etc. Trata-se do estágio de erosão de qualquer referência institucional e da emergência de um novo tipo de consumo subjetivo, emocional ou experiencial, muito mais voltado para a satisfação do eu do que para a exibição social e a busca de status, anseios que teriam caracterizado a segunda fase.

Assim é que o objetivo do hiperconsumidor é "tornar a existência materialista mais qualitativa e mais equilibrada", sem abrir mão das vantagens do mundo moderno. Não há nada de ascético na nova espiritualidade new age. Pelo contrário, "os ideais de renúncia ao mundo foram trocados pelas técnicas de auto-ajuda que supostamente proporcionam a uma só vez êxito material e paz interior, saúde e confiança em si [...], em outras palavras, a felicidade interior, sem que seja preciso renunciar ao que quer que seja de exterior (conforto, sucesso profissional, sexo, lazeres)" (p. 351). Paradoxos, enfim...

Emergem, também, as novas formas de consumo "responsável". A recusa a um "consumismo sem consciência" é um exemplo claro do hiperindividualismo que caracteriza essa terceira fase do consumo em que vivemos. O "consumo consciente" significa consumir melhor, com mais qualidade e de forma mais responsável para com o meio ambiente, representando uma "forma de suspeita em relação às grandes instituições, à reflexividade dos comportamentos individuais, às buscas qualitativas" (p. 345). Isto é, consome-se, aspirando à autonomia subjetiva - traduzida como um direito de escolha e de responsabilização pessoal por essas escolhas - e negando-se a imagem do "fantoche-consumidor" alienado da primeira e segunda fases da sociedade de consumo.

Mas, nessa pretensa autonomia, há uma dependência do consumidor com relação à dimensão imaginária das marcas, devido ao poder que essas teriam em direcionar as escolhas dos nossos objetos de consumo. As marcas assumem o lugar de uma "autoridade" sobre a desorientação e as dúvidas com relação a que escolhas fazer em um tipo de sociedade na qual os estilos de vida e os medos de perigos reais se multiplicam, tais como os riscos de uma hecatombe ambiental, as formas de violência urbana, dentre outros. Trata-se, em suma, de mais um paradoxo apontado pelo autor, pois o hiperconsumidor que adquire a autonomia e a responsabilidade pelos seus atos de consumo, também deve se haver com a impotência sobre o controle do próprio corpo ou do meio em que vive, prova da multiplicação de marcas e especialistas em nos dizer como devemos conduzir melhor nossas mais íntimas escolhas.

$\mathrm{Na}$ segunda parte do livro, questionam-se os paradoxos de uma época na qual nunca se teve tanto acesso às benesses do consumo e, portanto, à felicidade que sempre esteve a ele atrelada, ao mesmo tempo em que também emergem tipos inéditos de conflitos, sob a forma de ansiedades, depressões, pânicos, carências de auto-estima. Aqui, as "pílulas da felicidade" assumem lugar central para a solução dos nossos problemas, e a busca da felicidade "se abriga sob a égide da intervenção técnica, do medicamento, das próteses químicas" (p. 57). O autor nos faz ver que, muitas vezes, essas formas de consumo acabam por ocultar ou negar o enfrentamento dos nossos reais problemas.

Lipovetsky chega mesmo a reconhecer a positividade presente na superficialidade consumista ao admitir que o consumo representa uma fonte real de satisfação, mesmo não sendo sinônimo de felicidade. Daí a idéia de uma "felicidade paradoxal". Como esclarecer tal paradoxo? O autor retorna à utopia da felicidade para demonstrar que a "ideologia do capitalismo de consumo" constituiria apenas uma etapa tardia da crença no alcance da felicidade pelo progresso técnico. Assim, a sociedade do hiperconsumo também teria se desenvolvido em nome da busca da felicidade.

É como se o autor dissesse que o problema não estaria no consumo em si. Esvaziada de valores, resta à sociedade depositar no consumo os ideais de moralidade, ética, solidariedade, enfim, de felicidade. Tratar-se-ia, portanto, de não demonizar o consumo, mas de desinvesti-lo de um ideal fadado ao fracasso. Afinal, "quem fala da felicidade com freqüência tem os olhos tristes", já dizia o poeta francês Louis Aragon. Embora não dê razão ao poeta, Lipovetsky escorrega em seus próprios paradoxos, ao admitir que haja algo de impossível, de sofrido, de inconsciente, de incontrolável na experiência da felicidade.

Se a promessa de felicidade da sociedade de hiperconsumo se impõe como nosso horizonte único, por que não a aceitar como "um complexo de mitos, de sonhos, de significações imaginárias que, impulsionando objetivos e confiança no futuro, favorece a reoxigenação de um presente muitas vezes esgotado..." (p. 339) por todas as promessas não cumpridas da modernidade?

Trata-se de uma aposta paradoxal, que requer escolhas e riscos. Dilemas, sem dúvida, próprios de uma sociedade de hiperconsumo. 